\title{
HUBUNGAN ANTARA RELIGIOUSITAS DENGAN KENAKALAN REMAJA PADA SISWA KELAS XI MAN SURADE KABUPATEN SUKABUMI
}

\author{
Robana, Fenti Hikmawati, dan Ening Ningsih \\ Fakultas Psikologi UIN Sunan Gunung Djati Bandung, Jl. A.H Nasution No. 105 Bandung \\ email: ening_aci@gmail.com
}

\begin{abstract}
Abstrak
Penelitian ini bertujuan untuk memahami hubungan antara religiusitas dengan kenakalan remaja. Proporsional sampling digunakan dengan mengambil sampel sebanyak 74 siswa kelas XI Madrasah Aliyah Negeri Surade Kabupaten Sukabumi Tahun Ajaran 2011/2012. Rancangan penelitian adalah non-experimental dengan metode korelasional. Alat ukut yang digunakan adalah Skala Religiusitas (60 item) dan Skala Kenakalan Remaja (59 item). Hasil menunjukkan 61\% siswa memiliki tingkat religiusitas yang tinggi dan 53\% siswa memiliki tingkat kenakalan remaja yang rendah. Analisis korelasi menghasilkan koefisien korelasi sebesar -0,597, artinya religiusitas berhubungan negatif dengan kenakalan remaja.
\end{abstract}

Kata Kunci : Remaja, Agama, dan Kenakalan remaja

\begin{abstract}
This research aims to understand correlation between religiousity and juvenile delinquency. Proporsonal sampling used taking 74 students of grade XI Madrasah Aliyah Negeri Surade academic year 2011/2012. Research design is nonexperimental using correlational method. Instruments used are religiousity scale (60 itms) and juvenile delinquency scale (59 items). Result shows that $61 \%$ students have high religiousity level and 53\% students have low juvenile delinquency level. Correlation analysis result cooficient correlation -0,579 meaning that religiousity negatively correlated with juvenile delinquency.
\end{abstract}

Keyword: Teenager, Religion, juvenile delinquency

\section{PENDAHULUAN}

Manusia diciptakan Allah SWT hanyalah untuk taat dan beribadah kepadaNya dengan cara melaksanakan perintah dan menjauhi segala larangan-Nya. Tapi seiring perkembangan zaman manusia mulai melupakan perintah Tuhan dan melakukan perbuatan-perbuatan yang tidak sesuai dengan norma agama dan norma masyarakat seperti melakukan perjudian, mabuk-mabukan, perzinahan (seks bebas), bahkan pembunuhan. ASkhirnya Allah Swt mengutus Nabi dan Rasul untuk mengembalikan manusia kepada ajaran agama yang lurus serta menyempurnakan akhlak guna membimbing perilaku manusia dalam kehidupan sehari-hari.

Agama merupakan sistem nilai yang memuat norma-norma kehidupan dan menjadikan kerangka acuan dalam 
bersikap dan bertingkah laku. Menurut Mc. Guire (1981) (dalam Jalaludin, 2009: 306) sistem nilai yang berdasarkan agama dapat memberi individu dan masyarakat perangkat sistem nilai dalam bentuk keabsahan dan pembenaran dalam mengatur sikap individu dan masyarakat.

Agama sering diidentikkan dengan religiusitas. Meski berakar kata sama, namun dalam penggunaannya istilah religiusitas mempunyai makna yang berbeda dengan religi atau agama. Agama menunjuk pada aspek formal yang berkaitan dengan aturan-aturan dan kewajiban-kewajiban, sedangkan religiusitas menunjuk pada aspek religi yang telah dihayati oleh individu di dalam hati (Mangunwijaya,1986: 11). Religiusitas diartikan sebagai seberapa jauh pengetahuan, seberapa kokoh keyakinan, seberapa pelaksanaan ibadah dan kaidah dan seberapa dalam penghayatan atas agama yang dianutnya. Bagi seorang Muslim, religiusitas dapat diketahui dari seberapa jauh pengetahuan, keyakinan, pelaksanaan dan penghayatan atas agama Islam (Nashori dan Diana Mucharam, 2002: 71).

Religious Commitment atau komintmen beragama adalah kemampuan seseorang dalam menerapkan dan menginternalisasikan nilai-nilai keagamaan kedalam kehidupannya dan tercermin dalam sikap dan perilakunya. Dalam istilah Indonesia religious commitment sering diartikan dengan religiusitas, oleh karena itu penulis selanjutnya akan menggunakan istilah religiusitas dalam pembahasan skripsi ini. Religiusitas mencakup : dimensi keyakinan (ideological dimension), dimensi ritual (ritualisme dimensi), dimensi pengalaman atau penghayatan (experient dimensi), dimensi pengetahuan (intelektual dimensi), dan dimensi konsekuensi (konsequential dimensi) (Ancok, 2005: 76).

Remaja menaruh minat pada agama dan menganggap agama berperan penting dalam kehidupan. Minat pada agama antara lain tampak dengan membahas masalah agama, mengikuti pelajaranpelajaran agama di sekolah dan perguruan tinggi dan mengikuti berbagai upacara agama (Hurlok, 1980: 222). Apabila seorang remaja tidak mempunyai pedoman hidup atau dalam hal ini adalah agama, maka dalam situasi bingung dan konflik batin akan menyebabkan remaja berada di persimpangan jalan. Sulit untuk menentukan pilihan yang tepat. Dalam situasi yang demikian itu, maka peluang munculnya perilaku menyimpang akan terkuak lebar (Jalaludin, 2009: 82).

Masa remaja merupakan usia dimana individu berintegrasi dengan masyarakat dewasa atau masa transisi dimana terjadi perubahan pada dirinya yang mencakup kematangan mental, emosional, sosial dan fisik (Hurlock, 1980: 202).

Pada masa transisi tersebut kemungkinan dapat menimbulkan masa krisis, yang ditandai dengan kecenderungan munculnya perilaku menyimpang. Perilaku menyimpang tersebut pada kondisi tertentu akan menjadi perilaku yang mengganggu. Melihat kondisi tersebut apabila didukung oleh lingkungan yang kurang kondusif baik itu di lingkungan sekolah maupun di lingkungan keluarga karena kurangnya penanaman nilai-nilai agama terhadap remaja maka akan menjadi pemicu timbulnya berbagai penyimpangan perilaku dan perbuatan-perbuatan negatif yang melanggar aturan dan norma yang ada di masyarakat yang biasanya disebut dengan kenakalan remaja.

Kenakalan remaja adalah perilaku jahat atau kenakalan anak muda, yang disebabkan oleh satu bentuk pengabaian sosial, sehingga mereka mengembangkan bentuk perilaku yang menyimpang (Kartono, 2011: 6). Sedangkan kenakalan remaja menurut Sudarsono (2004: 6) adalah suatu perbuatan yang bertentangan dengan norma-norma yang ada dalam masyarakat tempat ia hidup atau tinggal, 
atau suatu perbuatan anti-sosial yang di dalamnya terkandung unsur-unsur anti normatif.

Paradigma kenakalan remaja lebih luas cakupannya dan lebih dalam bobot isinya. Kenakalan remaja tersebut meliputi perbuatan-perbuatan yang sering menimbulkan keresahan di lingkungan masyarakat, sekolah maupun keluarga. Adapun perilaku yang ditimbulkan antara lain pencurian oleh remaja, perkelahian dikalangan anak didik yang kerap kali berkembang menjadi perkelahian antara sekolah atau yang disebut dengan tawuran, mengganggu wanita di jalan yang pelakunya anak remaja (Sudarsono, 2004: 6).

Di Indonesia, gejala peningkatan kenakalan remaja tersebut sering kita lihat melalui berbagai media massa mengenai pelanggaran-pelanggaran yang dilakukan oleh remaja yang telah mengarah pada perilaku menyimpang, diantaranya adalah sebagai berikut:

Komnas Pendidikan Anak menyatakan sebanyak 62,7 persen remaja di Indonesia pernah melakukan hubungan layaknya suami istri. Sementara data dari BKKBN menyatakan sebanyak 51 persen remaja pernah melakukan seks bebas dan menurut data dari BNN dari tahun 2003 sampai 2010 terjadi kenaikan transaksi narkoba sebanyak 300 persen. "Dari data yang ada kondisi ini sudah dibatas menghawatirkan, sebab seks bebas dan narkoba merupakan permasalahan terbesar bagi remaja yang belum ada solusi konkrit dari pemerintah," kata Dedi kepada Pasundan Ekspres (Jpnn.com: 2012).

Warga Kota Bogor, Jawa Barat, gempar. Heboh, lantaran beredarnya video porno. Video porno itu direkam berdurasi 16 menit lebih, melalui kamera laptop yang diperankan oleh salah seorang siswi Madrasah Tsanawiyah setempat bersama pacarnya, staf tata usaha. Adegan yang dilakukan, terlihat jelas. Layaknya sepasang suami istri, padahal keduanya, berinsial RN dan $\mathrm{HN}$ belum menikah. RN, siswi madrasah tsanawiyah yang dimaksud, masih berusia belia. Pihak sekolah saat dikonfirmasi tak memungkiri adegan panas itu dilakukan oleh salah seorang muridnya. "Memang benar, siswi itu dari sekolah kita," ujar salah seorang pihak sekolah saat dikonfirmasi wartawan, Rabu (4/4/2012) kemarin. Pria sang kekasih siswi dalam vidoe itu, kini sudah diberhentikan sebagai salah seorang staf tata usaha sekolah kekasihanya. Sementara pasangannya, RN, masih menunggu jawaban dari Kementerian Agama. Siswi yang dimaksud juga terancam tak bisa mengikuti ujian nasional karena sudah dicoret sebagai peserta didik (Rachmat: 2012).

Dinas Pendidikan Kota Sukabumi, Jawa Barat akan memperketat pengawasan pada pelajar yang dicurigai menjadi anggota geng motor. Pengawasan tersebut untuk mencegah pelajar di kota itu ikut menjadi anggota geng motor. Sebagian besar pelajar SMA di Kota Sukabumi memakai sepeda motor untuk berangkat ke sekolah. "Karena pelajar yang menggunakan motor untuk kendaraan menuju sekolah cukup banyak yang berpotensi ikut menjadi anggota geng motor," kata Kepala Disdik Kota Sukabumi, Ayep Supriatna, seperti dimuat Kompas.com (2/4/2012). Ayep mencontohkan aksi kekerasan yang dilakukan oleh geng motor, yakni kasus tawuran antar-geng motor yang menyebabkan satu orang pelajar, yakni Rizki Maulana (16) pelajar SMAN I Kota Sukabumi, tewas dikeroyok anggota geng motor pada Minggu (25/3/2012) lalu. (Akhwani Subkhi, 2012)

Berdasarkan pengamatan peneliti, fenomena kenakalan remaja juga terjadi pada siswa Madrasah Aliyah (MAN 1) yang berada di wilayah Kecamatan Surade Kabupaten Sukabumi. Berdasarkan wawancara pada sekelompok siswa yang sedang istirahat di kantin sekolah yang berjumlah 6 orang, 3 diantaranya sering telat masuk sekolah, 4 orang siswa 
merokok, dan 2 orang siswa suka ikut tawuran. Hal ini juga didukung dengan pernyataan dari pihak sekolah yaitu dari Wakil Kepala Madrasah (Wakamad) Bidang Kesiswaan dan guru Bimbingan Konseling (BK), beliau mengatakan ada beberapa kasus pelanggaran siswa diantaranya yaitu tawuran antar sekolah, kabur pada saat jam istirahat dan ketika disusul ketahuan merokok dengan menggunakan seragam sekolah. Ada juga siswa yang sering kesiangan padahal dari rumahnya membawa kendaraan bermotor dan berangkat pagi, tapi ternyata ketika ditelusuri oleh pihak sekolah siswa tersebut sengaja kesiangan dan berhenti di warung untuk minum kopi dan merokok (wawancara dengan Guru BK dan Wakamad Kesiswaan: Selasa, 13 Maret 2012).

Padahal Madrasah Aliyah Surade sarat dengan muatan Pendidikan Agama Islam. Kadar dan bobotnya lebih banyak dibandingkan dengan Sekolah Menengah Umum yang lainnya. Hal ini dapat dilihat pada pelajaran Akidah Akhlahk, Fiqih, Quran Hadits, Sejarah Kebudayaan Islam dan Bahasa Arab. Bahkan ada juga sebagian dari mereka yang bersekolah sekaligus tinggal di pesantren. Menurut Zakiah Drajat (1994) bahwa salah satu faktor yang dapat menyebabkan kenakalan remaja adalah kurangnya pendidikan agama. Hal ini bertolak belakang dengan sebagian siswa di Madrasah Aliyah, mereka yang sering mendapatkan pelajaran Agama Islam dan suka melakukan kegiatan keagamaan serta melaksanakan perintah Allah seperti berpuasa, sering melaksanakan shalat, menunaikan ibadah zakat dan lain sebagainya ternyata disisi lain mereka melakukan tawuran, merokok, atau kabur pada saat jam pelajaran. Padahal seharusnya religiusitasnya tinggi maka kenakalan remaja akan rendah karena agama mengajarkan kebaikan bukan sebaliknya.

Berdasarkan fenomena yang telah dipaparkan sebelumnya, peneliti merasa tertarik untuk melakukan penelitian mengenai religiusitas dengan kenakalan remaja dengan judul penelitian "Hubungan Antara Religiusitas dengan Kenakalan Remaja" dengan subjek penelitian siswa kelas XI di Madrasah Aliyah Negeri (MAN) Surade Kab. Sukabumi.

Berdasarkan uraian yang ada pada latar belakang masalah, maka yang menjadi permasalahan dalam penelitian ini adalah :

1. Bagaimana gambaran religiusitas siswa kelas XI Madrasah Aliyah Negeri Surade Kabupaten Sukabumi?

2. Bagaimana gambaran perilaku kenakalan remaja pada siswa kelas XI Madrasah Aliyah Negeri Surade Kabupaten Sukabumi ?

3. Seberapa besar hubungan antara religiusitas dengan perilaku kenakalan remaja pada siswa kelas XI Madrasah Aliyah Negeri Surade Kabupaten Sukabumi?

Adapun tujuan dari penelitian ini adalah untuk mengetahui :

1. Gambaran religiusitas siswa kelas XI Madrasah Aliyah Negeri Surade Kabupaten Sukabumi.

2. Gambaran perilaku kenakalan remaja pada siswa kelas XI Madrasah Aliyah Negeri Surade Kabupaten Sukabumi.

3. Hubungan antara religiusitas dengan perilaku kenakalan remaja pada siswa kelas XI Madrasah Aliyah Negeri Surade Kabupaten Sukabumi.

Secara teoritis, kegunaan penelitian ini diharapkan dapat memperkaya keilmuan terutama dalam bidang psikologi dan dapat juga dijadikan sebagai salah satu rujukan untuk peneliti lainnya dalam penelitian yang berkenaan dengan religiusitas ataupun kenakalan remaja.

Kegunaan praktis dari penelitian ini akan berguna bagi para guru, khususnya guru Bimbingan Konseling (BK) di Madrasah Aliyah Negeri Surade sebagai tambahan informasi dan menjadi bahan referensi baik dalam upaya pencegahan 
kenakalan remaja maupun dalam menangani kasus kenakalan remaja yang terjadi, terutama yang berkaitan dengan masalah kenakalan remaja dan religiusitas.

Penelitian ini dilakukan dengan menggunakan desain penelitian korelasional. Penelitian korelasional bertujuan untuk menemukan ada tidaknya hubungan antara dua variabel yang diteliti. Dengan desain korelasi seorang peneliti dapat mengetahui hubungan variasi dalam sebuah variabel dengan variabel lainnya. Besarnya hubungan antara dua variabel yang diteliti dinyatakan dalam bentuk koefisien korelasi (Sudjana, 1996 : 367).

Komitmen beragama yang tercermin dalam dimensi keberagamaan yaitu: dimensi keyakinan (ideological dimension), dimensi ritual (ritualisme dimensi), dimensi pengalaman atau penghayatan (experient dimensi), dimensi pengetahuan (intelektual dimensi), dan dimensi konsekuensi (konsequential dimensi) menurut Glock dan Stark ( dalam Ancok, 2005: 76)

Secara operasional religiusitas dilihat dari seberapa kokoh keyakinan, seberapa tekun pelaksanaan ibadah, seberapa dalam pengetahuan agama, dan seberapa dalam pegalaman dan penghayatan agama yang dianut seseorang berdasarkan indikator yang mencakup:

1) Dimensi keyakinan yaitu menunjuk pada seberapa dalam tingkat keyakinan seorang Muslim terhadap kebenaran ajaran-ajaran agamanya, terutama terhadap ajaran-ajaran yang bersifat fundamental dan dogmatik. Keyakinan ini menyangkut iman kepada Allah, iman kepada Malaikat, iman kepada Nabi dan Rasul, iman kepada hari kiamat, dan iman kepada qadha dan qodar.

2) Dimensi ritual menunjuk pada seberapa tingkat kepatuhan muslim dalam mengerjakan kegiatan-kegiatan ritual sebagaimana disuruh dan dianjurkan oleh agamanya dalam hal ini mengucapkan syahadat, taat dalam melaksanakan ibadah shalat, zakat, puasa dan haji.

3) Dimensi pengamalan atau akhlak menunjuk pada perilaku Muslim yang dimotivasi oleh ajaran-ajaran agamanya, yaitu bagaimana individu berelasi dengan dunianya, terutama dengan manusia lain. ibadah mahdoh dan ghoiru mahdoh.

4) Dimensi pengetahuan menunjuk pada seberapa jauh tingkat pengetahuan dan pemahaman muslim terhadap ajaranajaran agamanya, terutama mengenai ajaran-ajaran pokok dari agamanya, sebagaimana termuat dalam kitab sucinya yaitu tauhid, ibadah, syariah dan muamalah.

5) Dimensi pengalaman atau penghayatan menunjuk pada seberapa jauh tingkat seorang muslim dalam merasakan dan mengalami perasaan dan pengalamanpengalaman dari keyakinan, praktik keagamaan, penghayatan dan pengetahuan.

Untuk menunjukkan tinggi rendahnya tingkat religiusitas akan dilihat dari skor subjek berdasar pada alat ukur skala religiusitas yaitu semakin tinggi skor pada skala ini maka tingkat religiusitas semakin tinggi, begitu pun sebaliknya semakin rendah skor pada skala ini maka tingkat religiusitas semakin rendah.

Kenakalan remaja adalah perilaku jahat atau kenakalan anak-anak muda, yang disebabkan oleh satu bentuk pengabaian sosial, sehingga mereka mengembangkan bentuk perilaku menyimpang (Kartono, 2011: 6).

Kenakalan remaja yang dimaksud dalam penelitian ini yaitu perilaku menyimpang yang ditunjukkan dari berbagai aspek yang meliputi:

1) Kenakalan terisolir yaitu adanya keinginan meniru dan ingin konform dengan gangnya, bergabung dalam gang untuk mendapatkan kedudukan hebat, pengakuan dan prestise tertentu, berasal dari keluarga berantakan, tidak harmonis, dan mengalami banyak 
frustasi, memuaskan semua kebutuhan dasarnya di tengah lingkungan kriminal, bereaksi terhadap tekanan dari lingkungan sosial, mereka mencari panutan dan rasa aman dari kelompok gangnya.

2) Kenakalan neurotik yaitu adaptasi pasif, menerima norma dan nilai subkultur gang yang kriminal, perilaku jahat merupakan alat pelepas ketakutan, kecemasan dan kebingungan batinnya, memiliki ego yang lemah, dan cenderung mengisolir diri dari lingkungan, perilakunya menunjukkan kualitas kompulsif (paksaan).

3) Kenakalan psikopatik yaitu dibesarkan dalam lingkungan keluarga yang ekstrim, brutal, diliputi banyak pertikaian keluarga, berdisiplin keras namun tidak konsisten, dan orangtuanya selalu menyia-nyiakan mereka, dan tidak mampu menjalin hubungan emosional yang akrab dan baik dengan orang lain, tidak mampu menyadari arti bersalah, berdosa, setelah melakukan pelanggaran, egoistis, anti sosial dan selalu menentang apa dan siapapun.

4) Kenakalan defek moral yaitu selalu melakukan tindakan anti sosial, selalu ingin melakukan perbuatan kekerasan, penyerangan dan kejahatan, merasa cepat puas dengan prestasinya, namun perbuatan mereka sering disertai agresivitas yang meledak.

Untuk menunjukkan tinggi rendahnya tingkat kenakalan remaja akan dilihat dari skor subjek berdasar pada alat ukur skala kenakalan remaja yaitu semakin tinggi skor pada skala ini maka tingkat kenakalan remaja semakin tinggi, begitu pun sebaliknya semakin rendah skor pada skala ini maka tingkat kenakalan remaja semakin rendah.

Subjek penelitian adalah benda, hal, atau orang, tempat data untuk variabel penelitian melekat dan yang dipermasalahkan (Arikunto, 2002 : 116). Pada penelitian ini subjek yang akan diteliti adalah siswa kelas XI Madrasah
Aliyah Negeri Surade. Dipilih dengan pertimbangan bahwa pada saat kelas sebelas siswa masuk pada fase transisi dimana siswa atau remaja mengalami ketidakstabilan dan kebingungan dalam menghadapi peranan baru (situasi sosial) seperti dalam pencarian identitas diri ataupun pencarian pertemanan. Dengan kondisi yang tidak stabil (labil) bisa saja terjadi pencarian identitas diri yang negatif ataupun karena pengruh teman sebaya (konformitas ), sehingga akhirnya salah bergaul dan dapat memberikan peluang kepada siswa untuk melakukan penyimpangan.

Adapun karakteristik subjek dalam penelitian ini adalah sebagai berikut:

a. Siswa yang terdaftar dan masih aktif sekolah pada semester genap/enam di tahun ajaran 2011/2012. Hal ini dilihat dari telah membayar SPP dan memiliki presentase kehadiran yang mencapai 75\% pada semester genap atau enam pada tahun ajaran 2011/2012.

b. Berusia 18-21 tahun sesuai dengan usia perkembangan remaja.

Sesuai dengan pendapat Arikunto (2002: 120) bahwa jika peneliti memiliki subjek kurang dari 100 lebih baik diambil semua sehingga penelitiannya merupakan penelitian populasi, namun apabila jumlah subjek lebih dari 100 orang maka dapat diambil sampel untuk dijadikan subjek sebanyak $10-15 \%$ atau $20-25 \%$. Dalam hal ini peneliti mengambil sampel $25 \%$ dari populasi yang sesuai dengan kriteria dari setiap jurusan, untuk setiap jurusan diambil perwakilan untuk menjadi sampel.

\section{HASIL PENELITIAN}

\section{Kategori Religiusitas}

Berikut ini gambaran yang akan peneliti jelaskan, yang berkenaan dengan religiusitas siswa Madrasah Aliyah Negeri Surade Kabupaten Sukabumi. Berdasarkan hasil perhitungan SPSS (Statistical Program for Social Science) versi 17 diperoleh mean atau nilai rata-rata adalah 272,3 , 
range 53, nilai minimum 254, nilai maksimum 298 dan nilai median atau titik tengah adalah 273. Nilai median diperoleh jika semua data diurutkan dan dibagi dua sama besar. Hal ini menunjukkan jika keseluruhan data diurutkan dan dibagi dua sama rata, maka nilai religiusitas subjek $50 \%$ berada di atas 273 dan $50 \%$-nya lagi berada di bawah 273 .

Untuk lebih jelasnya mengenai sebaran data variabel religiusitas dapat dilihat pada histogram berikut ini:

\section{Gambar 1 Histogram Sebaran Data Religiusitas}

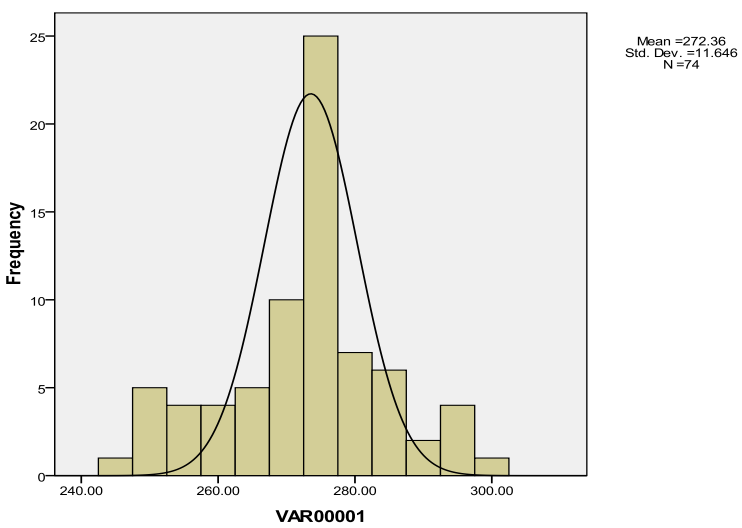

Selanjutnya untuk mengetahui tinggi rendahnya religiusitas subjek, maka peneliti membuat norma menjadi dua kategori yaitu religiusitas tinggi dan rendah. Hal ini dilakukan karena data berdistribusi ordinal.

Dari tabel 1 di atas, maka diperoleh nilai median sebesar 273. Dengan demikian, subjek dikatakan memiliki tingkat religiusitas yang tinggi apabila mempunyai skor lebih dari 273 dan dikatakan memiliki tingkat religiusitas yang rendah apabila mempunyai skor kurang dari 273.

Berdasarkan tabel 3, diketahui bahwa data yang diperoleh dari variable religiusitas, subjek sebesar 45 (61\%) siswa memiliki tingkat religiusitas yang tinggi dan 29 (39\%) siswa memiliki tingkat religiusitas rendah.

\section{Kategori Kenakalan Remaja}

Berikut ini gambaran yang akan peneliti jelaskan, yang berkenaan dengan kenakalan remaja siswa kelas XI Madrasah Aliyah Negeri Surade Kabupaten Sukabumi. Berdasarkan hasil perhitungan SPP (Statistical Program for Social Science) versi 17 diperoleh data mean atau nilai rata-rata adalah 93,2 range 56, nilai minimum 69 , nilai maksimum 125 dan nilai median atau titik tengah adalah 91. Nilai ini diperoleh jika semua data diurutkan dan dibagi dua sama besar. Hal ini menunjukan jika keseluruhan data diurutkan dan dibagi dua sama rata, maka nilai religiusitas subjek $50 \%$ berada di atas 91 dan $50 \%$-nya lagi berada di bawah 91. Untuk lebih jelasnya mengenai sebaran data variabel kenakalan remaja dapat dilihat pada histogram berikut ini:

Gambar 2 Histogram Sebaran Data Kenakalan Remaja

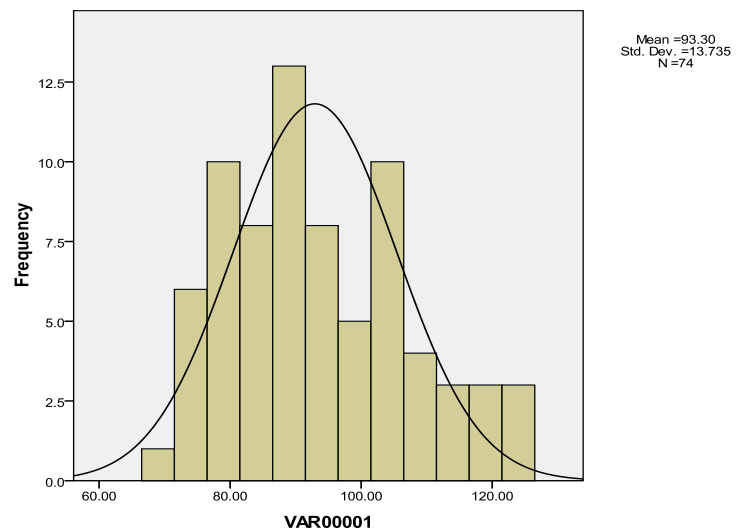

Selanjutnya untuk mengetahui tinggi rendahnya kenakalan remaja, maka peneliti membuat norma menjadi dua kategori yaitu kenakalan remaja tinggi dan rendah.

Dari table 3, maka diperoleh nilai median sebesar 91. Dengan demikian siswa dikatakan memiliki tingkat kenakalan remaja yang tinggi apabila mempunyai skor lebih dari 91 dan dikatakan memiliki tingkat kenakalan 
remaja yang rendah apabila mempunyai skor kurang dari 91. Berdasarkan pada norma tersebut diatas, didapatkan data variabel kenakalan remaja diketahui bahwa data yang diperoleh dari variabel kenakalan remaja sebesar 36 (49\%) siswa yang memiliki tingkat kenakalan remaja yang tinggi dan 38 (51\%) siswa yang memiliki tingkat kenakalan remaja yang rendah.

Adapun untuk mengetahui secara terperinci tingkat religiusitas dan tingkat kenakalan remaja maka dilakukan tabulasi silang. Berdasarkan pada table 8 dapat diketahui bahwa data yang diperoleh dari hasil tabulasi silang antara religiusitas dengan kenakalan remaja sebesar 12 siswa yang memiliki tingkat religiusitas tinggi dan kenakalan remaja tinggi, 33 siswa yang memiliki tingkat religiusitas tinggi dan kenakalan remaja rendah, 24 siswa memiliki religiusitas rendah dan kenakalan remaja tinggi, dan 5 siswa memiliki tingkat religiusitas rendah dan memiliki kenakalan remaja rendah.

\section{Hubungan Religiusitas dengan Kenakalan Remaja}

Berdasarkan penelitian yang telah dilakukan, diperoleh data mengenai variabel religiusitas dan kenakalan remaja. Kedua variabel tersebut dikorelasikan melalui perhitungan statistik untuk membuktikan hipotesis penelitian. Hipotesis penelitian ini adalah terdapat hubungan negatif antara religiusitas dengan kenakalan remaja siswa kelas XI Madrasah Aliyah Negeri Surade Kabupaten Sukabumi, dengan rumusan hipotesis sebagai berikut :

$\begin{array}{rlr}\mathrm{H}_{0}: r s \neq 0 \rightarrow & \text { Tidak } & \text { terdapat } \\ & \text { hubungan } & \text { antara } \\ & \text { religusitas } & \text { dengan } \\ & \text { kenakalan } & \text { remaja } \\ & \text { pada siswa } & \text { kelas XI } \\ & \text { MAN } & \text { Surade }\end{array}$

Kabupaten Sukabumi.

$\begin{array}{rlr}\mathrm{H}_{1}: r s<0 \rightarrow & \text { Terdapat } & \text { hubungan } \\ & \text { negatif } & \text { antara } \\ & \text { religusitas } & \text { dengan } \\ & \text { kenakalan } & \text { remaja } \\ & \text { pada siswa kelas XI } \\ & \text { MAN } & \text { Surade } \\ & \text { Kabupaten Sukabumi. }\end{array}$

Hipotesis tersebut akan diuji menggunakan uji korelasi Rank Spearman dengan kriteria uji : Tolak $\mathrm{H}_{0}$ jika harga dalam tabel $r_{s}$ hitung $\geq r_{s}$ tabel, harga $\mathrm{z}_{\text {hitung }} \geq \mathrm{z}_{\text {table }}$ atau nilai $\mathrm{P}_{\text {value }} \leq \alpha$ dengan $\alpha=0,05$. Sedangkan hasil perhitungan dan analisis statistik yang diperoleh untuk menguji hipotesis tersebut adalah sebagai berikut:

Berdasarkan hasil analisis statistik , diperoleh koefesien korelasi antara religiusitas dengan kenakalan remaja diperoleh skor $\mathrm{P}_{\text {value }}$ sebesar 0,00 dengan $\alpha=0,05$ yang artinya $P_{\text {value }}$ $\leq \alpha$, maka $\mathrm{H}_{0}$ ditolak dan $\mathrm{H}_{1}$ diterima yang artinya terdapat hubungan negatif antara religiusitas dengan kenakalan remaja pada siswa kelas XI Madrasah Aliyah Negeri Surade Kabupaten Sukabumi. Artinya apabila tingkat religiusitas siswa Madrasaha Aliyah Negeri Surade tinggi, maka tingkat kenakalan remaja siswa Madrasah Aliyah Negeri Surade akan rendah. Begitu pula sebaliknya, apabila kenakalan remaja siswa Madrasah Aliyah Negeri Surade rendah, umumnya religiusitas siswa Madrasah Aliyah Negeri Surade akan tinggi. Apabila dilihat dari hasil analisis korelasional antara religiusitas dengan kenakalan remaja, maka diperoleh $\mathrm{r}_{\mathrm{s}}=-0,597$, yaitu memiliki derajat hubungan yang sedang menurut skala Guillford. Kemudian koefesien determinasi menunjukan $\mathrm{r}_{\mathrm{s}}{ }^{2}=0,356$ atau $35,6 \%$, menunjukan bahwa $35,6 \%$ variasi perubahan dalam variabel kenakalan remaja disebabkan atau ditentukan oleh variasi religiusitas dan sisanya sebanyak 
64,4\% disebabkan atau ditentukan oleh variabel lainnya atau faktor lain.

\section{PEMBAHASAN}

Berdasarkan hasil perhitungan, maka diketahui bahwa data yang diperoleh dari variabel religiusitas sebesar 45 siswa atau $61 \%$ siswa yang memiliki tingkat religiusitas yang tinggi dan 38 siswa atau $51 \%$ siswa yang memiliki tingkat kenakalan remaja yang rendah. Hal ini dapat terjadi karena Mandrasah Aliyah Negeri Surade merupakan Madrasah yang berbasis pada ajaran Islam, pelajaran agamanya lebih banyak dibandingkan sekolah lainnya. Selain itu diadakannya juga peringatan-peringatan hari besar Islam, dan dilaksanakannya juga praktek ibadah seperti siswa diharuskan mengikuti shalat Dzuhur berjamaah di Madrasah dan diharuskannya mengikuti tadarus al-Quran (membaca al-Quran) sebelum dimulainya pelajaran. Maka dari itu siswa/siswi Madrasah Aliyah Negeri Surade memiliki keyakinan yang kuat, pengetahuan agama yang luas, melaksanakan ibadah dengan tekun dan memiliki penghayatan dan pengalaman yang dalam terhadap agama karena aktivitas sehari-hari mereka tidak lepas dari ajaran agama.

Berdasarkan hasil tabulasi silang pada tabel 4.8 diketahui bahwa siswa Madrasah Aliyah Negeri Surade dikelompokkan dalam 4 kategori, yaitu yang pertama, siswa yang memiliki religiustas tinggi dan kenakalan remaja yang tinggi sebanyak 12 orang, hal ini menunjukkan bahwa ada faktor lain selain agama yang dapat menyebabkan kenakalan remaja seperti identitas diri yang negatif, kontrol diri yang rendah, pengaruh teman sebaya atau kurangnya dukungan orangtua.

Kedua, siswa yang memiliki religiusitas tinggi dan kenakalan remaja rendah sebanyak 33 orang, hal ini menunjukkan bahwa agama dapat menjadi kontrol atas semua tingkah laku siswa (Jalaludin, 2009: 313), sehingga dengan adanya religiusitas dalam diri seseorang dapat menekan sikap-sikap dan tingkah laku yang bertentangan dengan norma agama dan sosial, serta memunculkan sikap-sikap dan tingkah laku yang selaras dengan norma agama dan sosial, misalnya ketika seseorang mempunyai religiusitas yang tinggi maka orang tersebut akan melakukan hal-hal positif seperti tolongmenolong, menghormati orang lain, persaudaraan (perdamaian) dan sikap-sikap positif lainnya yang akan berdampak pada tingkah laku orang tersebut seperti tidak melakukan kebut-kebutan, perkelahian baik individu atau kelompok, mencuri, mabuk-mabukan, berkata kasar dan perilaku-perilaku a-sosial. Adapun pendapat lain menurut Sudarsono (2005: 6) bahwa internalisasi nilai-nilai keagamaan dapat mendidik kaum remaja memiliki rasa tanggung jawab kemasyarakatan dan memiliki penghayatan serta perilaku yang sesuai dengan perintah agama. Religiusitas seseorang berhubungan dengan kenakalan remaja dapat dijelaskan dari hubungan antara dimensi-dimensi religiusitas Islami dengan kenakalan remaja itu sendiri. Menurut Ancok (2005: 81) dimensi keyakinan atau dalam Islam disebut dengan akidah Islam menunjuk pada seberapa dalam tingkat keyakinan seorang Muslim terhadap kebenaran ajaran-ajaran agamanya, terutama terhadap ajaran-ajaran yang bersifat fundamental dan dogmatik. Dalam Islam isi dimensi keimanan menyangkut keyakinan tentang Allah, para malaikat, nabi/rasul, kitab-kitab Allah, surga dan neraka, serta qadha dan qadar. Selain dari pada itu menurut Komarudin (2010: 3) "orang yang memiliki religiusitas, di manapun orang itu berada agama dan keimanannya akan hadir dan akan memberikan pertimbangan terhadap semua keputusan yang diambilnya. Dengan demikian maka ketika serorang remaja sudah mempunyai keimanan yang kuat maka tidak aka berperilaku menyimpang baik itu dari norma agama maupun norma masyarakat karena mereka meyakini segala gerak-gerik perbuatan 
maupun ucapannya disaksikan oleh Allah SWT dan malaikat mencatatnya".

Menurut Ancok (2005: 81) "dimensi peribadatan (ritual) atau syari'ah menunjuk pada seberapa tingkat kepatuhan muslim dalam mengerjakan kegiatan-kegiatan ritual sebagaimana disuruh dan dianjurkan oleh agamanya. Dimensi ini menyangkut pelaksanaan shalat, puasa, zakat, haji, membaca al-Quran, doa, dzikir, ibadah kurban, iktikaf di mesjid, dan lain sebagainya".

Misalnya ketika seorang remaja sering melaksanakan shalat maka akan terjaga dari perbuatan keji dan munkar, kemudian ketika seorang remaja melaksanakan puasa maka syahwatnya akan terjaga dan terhindar dari perilaku yang tidak sesuai dengan norma agama dan masyarakat seperti seks bebas atau zina, dan lain sebagainya.

Dimensi pengetahuan atau ilmu menunjuk pada seberapa jauh tingkat pengeahuan dan pemahaman Muslim terhadap ajaran-ajaran agamanya, terutama mengenai ajaran-ajaran pokok dari agamanya, sebagaimana termuat dalam kitab sucinya. Dalam al-Quran pokok-pokok ajarannya yaitu rukun iman, rukun islam, hukum-hukum islam, sejarah dan sebagainya. Misalnya ketika seorang remaja mempunyai pengetahuan yang luas tentang agama maka tidak akan terjadi perilaku kenakalan remaja seperti tawuran, mabuk-mabukan, seks bebas, dan kenakalan-kenakalan lainnya karena agama mengajarkan perilaku berbuat baik (akhlakul karimah) bukan sebaliknya (akhlakul madzmumah).

Dimensi pengalaman atau penghayatan adalah dimensi yang menyertai keyakinan, pengamalan dan peribadatan. Dimensi penghayatan menunjuk pada seberapa jauh tingkat seorang Muslim dalam merasakan dan mengalami perasaan dan pengalamanpengalaman religius. Dalam Islam dimensi ini terwujud dalam perasaan dekat/akrab dengan Allah SWT, perasaan doa-doanya sering terkabul, perasaan tentram bahagia karena menuhankan Allah, perasaan bertawakal (pasrah diri) kepada Allah, perasaan khusuk ketika melaksanakan shalat atau berdoa, perasaan bersyukur kepada Allah, perasaan tergetar ketika mendengar adzan ata ayat al-Quran, perasaan mendapat peringatan atau pertolongan dari Allah. Apabila seorang remaja memiliki pengalaman dalam beragama baik itu pengalaman sendiri maupun pengalaman dari orang lain, misalanya ketika ia berbuat baik kepada orang lain, maka orang lain pun akan berbuat baik kepadanya atau pun sebaliknya ketika ia melakukan perbuatan yang dapat menyakiti orang lain seperti melecehkan, mencomoohkan, atau perbuatan kasar (fisik) maka ia akan di jauhi oleh orang lain bahkan mungkin banyak musuh, ketika seseorang sudah pernah mengalami hal demikian maka akan memberikan efek jera dan dijadikan pengalaman olehnya untuk tidak melakukan perbuatan seperti itu lagi.

Dimensi pengamalan atau akhlak menunjuk pada perilaku Muslim yang dimotivasi oleh ajaran-ajaran agamanya, yaitu bagaimana individu berelasi dengan dunianya, terutama dengan manusia lain. Dimensi ini meliputi perilaku suka menolong sesama, bekerjasama, berderma, menyejahterakan dan menumbuhkembangkan orang lain, menegakkan keadilan dan kebenaran, berlaku jujur, memaafkan, menjaga lingkungan hidup, menjaga amanat, tidak mencuri, tidak korupsi, tidak menipu, tidak berjudi, tidak mabuk-mabukkan, mematuhi norma Islam dalam perilaku seksual, dan sebagainya. Ketika seseorang sudah dapat menginternalisasikan nilai-nilai atau ajaran agama dalam kehidupanya maka setiap gerak langkahnya akan selalu diperhitungkan dengan baik, karena setiap apa yang diperbuatnya mengandung konsekuensi yaitu berupa reward (pahala) dan funishment (dosa) sehigga ia akan 
terjaga dari perbuatan menyimpang (maksiat).

Ketiga, siswa yang memiliki religiusitas rendah dan kenakalan remaja tinggi sebanyak 24 orang, hal ini menunjukkan bahwa kenakalan remaja yang terjadi pada sebagian siswa dikarenakan kurangnya/rendahnya religiusitas pada diri mereka. Hal ini sejalan dengan pendapat Zakiah Drajat (1996) bahwa rendahnya religiusitas pada diri remaja akan menyebabkan terjadinya perilaku penyimpangan (kenakalan remaja).

Keempat, siswa yang memiliki religiusitas rendah dan kenakalan remaja rendah sebanyak 5 orang, hal ini menunjukkan bahwa religiusitas tidak menjadi kontrol atas perilaku kenakalan remaja.

Dari uraian sebelumnya maka dapat ditarik kesimpulan bahwa terdapat hubungan negatif antara religiusitas dengan kenakalan remaja pada siswa kelas XI Madrasah Aliyah Negeri Surade, yaitu semakin tinggi tingkat religiusitas maka semakin rendah tingkat kenakalan remaja, begitu pula sebaliknya semakin rendah tingkat religiusitas maka semakin tinggi tingkat kenakalan remaja.

\section{SIMPULAN}

Berdasarkan hasil analisis dan pembahasan dapat ditarik simpulan bahwa terdapat hubungan antara religiusitas dengan kenakalan remaja pada siswa kelas XI Madrasah Aliyah Negeri Surade Kabupaten Sukabumi. Hal ini menunjukkan tiga hasil, yaitu :

1. Siswa kelas XI Madrasah Aliyah Negeri Surade Kabupaten Sukabumi yang memiliki religiusitas tinggi sebanyak $61 \%$ dan siswa yang memiliki religiusitas rendah sebanyak $39 \%$.

2. Siswa kelas XI Madrasah Aliyah Negeri Surade Kabupaten Sukabumi yang memiliki kenakalan remaja tinggi sebanyak $49 \%$ dan siswa yang memiliki kenakalan remaja rendah sebanyak $51 \%$.
3. Terdapat hubungan negatif antara religiusitas dengan kenakalan remaja pada siswa kelas XI Madrasah Aliyah Negeri Surade Kabupaten Sukabumi dengan derajat korelasi sedang. Sedangkan koefisien determinasi sebesar $35,6 \%$, artinya perubahan dalam variabel kenakalan remaja disebabkan atau ditentukan oleh variasi religiusitas dan $64,4 \%$ lainnya ditentukan oleh faktor lain.

\section{SARAN}

Berdasarkan hasil penelitian yang telah dilakukan, dengan memperhatikan keterbatasan-keterbatasan dalam penelitian ini, peneliti mengajukan saran-saran agar dapat dijadikan bahan pertimbangan yang ditujukan kepada:

\section{Siswa MAN Surade}

Peneliti menyarankan agar siswasiswi Madrasah Aliyah Negeri Surade lebih aktif dalam mengikuti kegiatankegiatan keagamaan seperti peringatanperingatan hari besar Islam, dan selalu hadir dalam mata pelajaran keagamaan karena untuk memperluas pengatahuan tentang keagamaan sehingga nantinya bisa mengaplikasikan nilai-nilai agama dalam kehidupan sehari-hari.

\section{Lembaga MAN Surade}

Pihak sekolah hendaknya lebih progress dalam hal meningkatkan kualitas keagamaan siswa-siswinya, seperti mengadakan kegiatan rohis (rohani Islam) yang dilaksanakan seminggu sekali, sering mengadakan peringatan-peringatan keagamaan yang harus diikuti oleh seluruh siswa ataupun dengan mengadakan tour keagamaan, melakukan sharing dengan siswa seperti dengan menghadirkan nara sumber yang pernah terjerumus kedalam perilaku yang menyimpang untuk berbagi pengalaman tentang akibat yang pernah dirasakannya. Selain itu pihak sekolah juga hendaknya lebih waspada terhadap faktor-faktor lain yang dapat menyebabkan siswa- 
siswinya terjerumus kedalam kenakalan remaja.

\section{Peneliti Selanjutnya}

Dalam penelitian ini masih terdapat kasus yang menarik dan perlu dijawab serta diteliti kembali, oleh karena itu peneliti lain disarankan untuk menggali variabel kenalakan remaja dengan variabel lain, misalnya dengan variabel kontrol diri atau variabel religusitas dengan altruisme.

\section{DAFTAR PUSTAKA}

Ahyadi, Aziz. 2005. Psikologi Agama. Bandung: Sinar Baru.

Ancok, J \& Nashori S, Fuat. 2005. Psikologi Islami. Yogyakarta : Pustaka Pelajar.

Arikunto, Suharsimi. 2002. Manajemen Penelitian. Jakarta: Rineka Cipta.

Azwar, Saifuddin. 2009. Metode penelitian. Yogyakarta : Pustaka Pelajar.

Azwar, Saifuddin. 2009. Penyusunan skala psikologi. Yogyakarta: Pustaka Pelajar.

Darajat, Zakiah. 1994. Peranan Agama dalam Kesehatan Mental. Jakarta: Gunung Agung.

Daud, Mohammad. 2006. Pendidikan Agama Islam. Jakarta.

Depag, 2004. Al-Qur'an dan Terjemahnya. Semarang: CV. Toha Putra.

Fatimah, Siti. 2011. Hubungan antara konformitas dengan Kenakalan Remaja pada siswa SMPN 1 Ciwidey Bandung. Universitas Islam Negeri Sunan Gunung Djati.

Friedenberg, Lisa. 1995. Psychological Testing Design Analysis and Use. Massachusetts: Allyn\&Bacon

Hidayat, Komarudin. 2010. Psikologi Agama. Jakarta Selatan: Hikmah.

Hurlock. Elizabeth B. 1980. Psikologi perkembangan suatu pendekatan sepanjang rentang kehidupan. Edisi Ke-Lima. Alih Bahasa Istiwidayanti dan Soedjarwo. Jakarta : Erlangga.
Kartono, Kartini. 2011. Patologi Sosial 2 Kenakalan Remaja cetakan ke-10. Jakarta : PT. Raja Grapindo Persada.

Mangunwijaya. 1986. Menumbuhkan Sikap Religiusitas Anak. Jakarta : Gramedia

Miftah F, Irfan. 2012. Peng eaktifan Mengikuti Penধ dan Komitmen Beraga erhadap Subjective Well Being pada Ibu-Ibu Pengajian Mi'roju Taqwa di Desa Paseh Kecamatan Paseh Kabupaten Sumedang.UIN Sunan Gunung Djati Bandung.

Monks, F. J, Knoers, A. M. P, and Haditono, S. R. 1999. Psikologi Perkembangan

Nashori, Fuad 2002. Mengembagkan Kreativitas dalam Perspektif Psikologi Islam. Yogyakarta: Menara Kudus.

Natta, Abudin. 2004. Metodologi Studi Islam. Jakarta: PT. Raja Grafindo Persada.

Papalia, D. E. 2008. Human Development. Jakarta : Kencana Prenada Media Group.

Rachmat, (April 2012) Video Siswi Tsanawiyah beradegan mesum beredar.

http://jakarta.tribunnews.com/2012/ 04/05/siswi-madrasah-tsanawiyahberdegan-mesum-beredar

Rahmat, Jalaludin. 2009. Psikologi Agama. Raja Grafindo Persada. Yogyakarta.

Rahmat, Jalaluddin. 2004. Psikologi Agama sebuah Pengatar. Bandung. Mizan.

Ramayulis, 2002. Psikologi Agama. Bandung: Kalam Mulia.

Santrock, John W. 2003. Perkembangan Remaja. Erlangga: Jakarta.

Sarwono, Sarlito. 2012. Psikologi Remaja edisi revisi. Jakarta: PT. Raja Grafindo Persada.

Siegel, Sidney. 1992. Statistik Non Parametri untuk Ilmu-ilmu Sosial. 